\title{
Virulence of Pythium Species Isolated from Wheat Fields in Eastern Washington
}

R. W. Higginbotham, Department of Crop and Soil Sciences, Washington State University, Pullman 99164-6420; T. C. Paulitz, USDA-ARS, Root Disease and Biological Control Unit, Pullman, WA 99164-6430; and K. K. Kidwell, Department of Crop and Soil Sciences, Washington State University, Pullman 99164-6420

\begin{abstract}
Higginbotham, R. W., Paulitz, T. C., and Kidwell, K. K. 2004. Virulence of Pythium species isolated from wheat fields in eastern Washington. Plant Dis. 88:1021-1026.

Although Pythium root rot in wheat (Triticum aestivum) is well documented, limited information is available concerning which species of Pythium are most responsible for disease damage. The objective of this study was to examine the variation in virulence on wheat among isolates of Pythium collected from cereal grain fields in eastern Washington. Isolates of nine Pythium species were tested for virulence on spring wheat cultivars Chinese Spring and Spillman. Cultivars were planted in pasteurized soil infested with Pythium isolates and placed in a growth chamber maintained at a constant $16^{\circ} \mathrm{C}$ and ambient humidity. Plant height, length of the first true leaf, and number of seminal roots were recorded, and roots were digitally scanned to create computer files that were analyzed using WinRhizo software. Pythium isolates caused a significant reduction $(P<0.05)$ in the number of root tips, root length, and length of the first leaf. Differences in virulence were detected among species and among isolates within species. Isolate Pythium debaryanum 90136 and P. ultimum 90038 were the most virulent and may prove useful in future disease screening assays of Triticum germ plasm.
\end{abstract}

Pythium root rot caused by Pythium spp. occurs in virtually all wheat fields in Washington State $(9,19)$, and this disease may be the most widely distributed yieldlimiting disease of wheat in North America (9). Infection with Pythium spp. causes a decrease in root mass, which leads to poor nutrient uptake, resulting in variable crop stands, decreased tiller numbers, varying maturity dates, and yield losses (33). Grain yields of wheat grown in Pythium-free soil have been reported to be 15 to $25 \%$ higher than those of wheat grown in Pythium-infested soil $(6-8,12,33)$. If embryo damage due to Pythium infection after planting is severe, seedlings often fail to emerge when infected with Pythium (11). Pythium root rot is prevalent in cool, wet soils covered with crop debris $(6,8,9)$, which is typical in direct-seeded wheat fields (31). An increased awareness of the environmental impacts of traditional tillage practices, such as wind and water erosion, nutrient leaching, and decreased soil organic matter, has caused many growers to shift to direct-seeded wheat production from conventional tillage $(18,31)$. This shift in production practices provides Pythium

Corresponding author: T. C. Paulitz

E-mail: paulitz@wsu.edu

Accepted for publication 13 May 2004.

Publication no. D-2004-0712-01R

This article is in the public domain and not copyrightable. It may be freely reprinted with customary crediting of the source. The American Phytopathological Society, 2004. species with an optimal environment for infecting wheat crops $(4,8)$.

Chamswarng and Cook (3) isolated and identified 10 Pythium spp. from soils in eastern Washington that were pathogenic to wheat. They found $P$. aristosporum, $P$. volutum, $P$. ultimum, $P$. sylvaticum complex, and $P$. irregulare to be the most virulent among identified isolates. Ingram and Cook (14) assessed the pathogenicity of four Pythium species on wheat, peas, lentils, and barley, and $P$. ultimum and $P$. irregulare were the most virulent species to wheat. Even though previous results demare pathogenic to wheat, it is not known whether variation in virulence exists among isolates within a given species, since only one isolate of each Pythium spp. was typically evaluated $(3,14)$. Due to variation in the distribution of Pythium spp. across environments (19), it is important to know which isolates within a given species are the most virulent, especially for germ plasm evaluations, where the goal is to identify genetic resistance to highly virulent isolates. Research on virulence of Pythium spp. on wheat has been conducted outside of the Pacific Northwest $(16,25,26,29,30)$; however, the virulence of isolates and species of Pythium from the Pacific Northwest is still largely unknown.

The objective of this research was to examine, in a controlled growth chamber environment, the virulence of isolates of various Pythium species collected from cereal grain fields in eastern Washington on two spring wheat cultivars. Virulence was quantified by effects of the pathogens on length of the first leaf, total root length, number of root tips, and percent emergence.

\section{MATERIALS AND METHODS}

To assess the inherent variation in virulence of Pythium spp. from eastern Washonstrated that a number of Pythium spp.

Table 1. Source of Pythium isolates tested for virulence on the spring wheat cultivars Chinese Spring and Spillman in growth chamber ${ }^{y}$ evaluations

\begin{tabular}{lcl}
\hline Pythium species & Isolate number & $\begin{array}{l}\text { Collection location } \\
\text { (city [WA], and county) }\end{array}$ \\
\hline P. paroecandrum & 90127 & Rockford, Spokane Co. \\
& 030130 & Provided by R. J. Cook \\
P. irregulare & 70007 & Dayton, Garfield Co. \\
P. rostratum & 020172 & Pullman, Whitman Co. \\
& 90025 & Sprague, Lincoln Co. \\
P. heterothallicum & 010116 & Pullman, Whitman Co. \\
P. debaryanum & 90084 & Garfield, Whitman Co. \\
& 020130 & Pullman, Whitman Co. \\
P. intermedium & 90116 & Steptoe, Whitman Co. \\
Pythium sp. (aff. echinulatum $)^{\mathrm{z}}$ & 90136 & St. John, Whitman Co. \\
& 010114 & Garfield, Whitman Co. \\
P. abappressorium & 020167 & La Crosse, Whitman Co. \\
& 020151 & Pullman, Whitman Co. \\
P. ultimum & 90063 & Harrington, Lincoln Co. \\
& 90089 & Dayton, Garfield Co. \\
& 020125 & Garfield, Whitman Co.
\end{tabular}

y Plants were grown in a growth chamber in pasteurized field soil amended with Pythium spp. at constant $16^{\circ} \mathrm{C}$ and 12 -h photoperiod.

${ }^{\mathrm{z}}$ Pythium sp. (aff. echinulatum) is an undescribed species with an internal transcribed spacer (ITS) sequence most similar to $P$. echinulatum; however, it is morphologically different from this species. (T. C. Paulitz, unpublished; C. A. Lévesque, personal communication). 
ington, 18 isolates were chosen for this study (Table 1). All isolates were collected from soil and roots in cereal grain fields in eastern Washington during the spring and summer of 2000 (19). These isolates were used to infest pasteurized field soil in growth chamber trials planted with spring wheat (Triticum aestivum L.) cultivars Spillman (PI 506350) and Chinese Spring (CItr 14108). Cultivars were chosen based on results from Smith et al. (23), where Chinese Spring and Spillman were highly susceptible and moderately susceptible to infection by Rhizoctonia solani, respectively. Chinese Spring is widely used for genetic studies and serves as a genetic model for wheat. Spillman was ranked fourth in hard red spring wheat acreage in Washington from 1998 to 2000 (28).

Inoculum was produced in 1-liter mason jars containing Ritzville silt loam soil collected from Washington State University Dryland Experiment Station in Lind, WA. Soil was amended with $1 \%(\mathrm{wt} / \mathrm{wt})$ ground rolled oats (Old Fashioned Quaker Oats, Chicago, IL) and then autoclaved twice (21). Jars were seeded with ten 1-cm square pieces from a 2-week-old potato dextrose agar (PDA) plate culture of each isolate, which was grown at $22^{\circ} \mathrm{C}$. Mason jars were manually shaken to cover agar pieces with soil. Isolates were grown at ambient room temperature $\left(\sim 22^{\circ} \mathrm{C}\right)$ for 3 weeks, with $10-\mathrm{ml}$ sterile water added to each jar after 1 week. After 1 month, inoculum was stored at $4^{\circ} \mathrm{C}$ and used within 2 to 3 months. New inoculum was made for each trial. Prior to the experiment, the inoculum was serially diluted and plated on Pythium selective media to determine inoculum densities (17). CFU per gram of dry soil were calculated from dilution plate counts. The inoculum consisted of oospores, sporangia, and hyphal swellings, usually colonizing the particles of rolled oats in the autoclaved soil. $P$. heterothallicum and Pythium sp. (aff. echinulatum) did not form oospores in single culture. Tests for virulence were carried out in tapered plastic tubes $(4 \mathrm{~cm}$ diameter $\times 20.5 \mathrm{~cm}$ long; Cone-tainers; Ray Leach Conetainer, Canby, OR) with drain holes plugged with cotton to prevent soil and moisture loss. Pasteurized Thatuna silt loam soil collected from the Plant Pathology Farm at Washington State University in Pullman was air-dried and infested with pathogen-containing soil from mason jars by manual agitation in plastic bags. Plastic Cone-tainers were filled with $130 \mathrm{~g}$ of inoculated soil with a target inoculum density of $500 \mathrm{CFU} \mathrm{g} \mathrm{g}^{-1}(5,7)$. Control treatments consisted of pasteurized soil without inoculum. The Cone-tainers, sus-

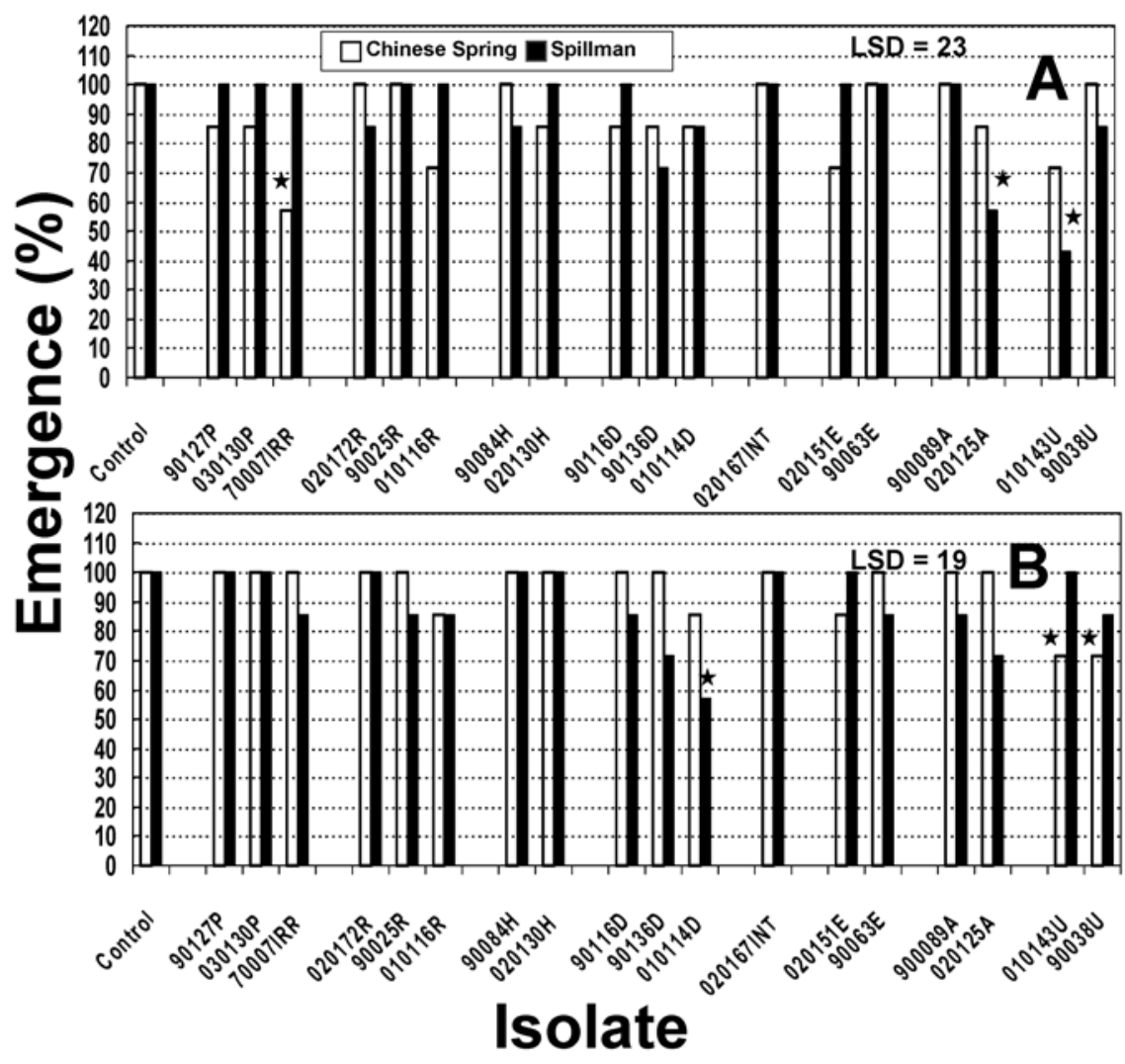

Fig. 1. Effect of isolates of Pythium on percent emergence of wheat cultivars Chinese Spring and Spillman $(\mathbf{A}=$ trial $1, \mathbf{B}=$ trial 2$)$. Bars with stars are significantly less than the noninoculated control treatments based on least significant difference $(P=0.05)$. LSD displayed in figure to determine significant differences among isolates was pooled across cultivars. $\mathrm{A}=P$. abappressorium, $\mathrm{D}=P$. debaryanum, $\mathrm{E}=P$. sp. $($ aff. echinulatum $), \mathrm{H}=P$. heterothallicum, $\mathrm{IRR}=P$. irregulare, $\mathrm{INT}=P$. intermedium, $\mathrm{P}=P$. paroecandrum, $\mathrm{R}=P$. rostratum, and $\mathrm{U}=P$. ultimum. pended in racks, were watered with $20 \mathrm{ml}$ of distilled water each and placed in a growth chamber at a constant temperature of $16^{\circ} \mathrm{C}$ and $80 \%$ relative humidity. Each tube was watered with $10 \mathrm{ml}$ of distilled water as needed to prevent desiccation.

After 7 days, each tube was watered with $10 \mathrm{ml}$ of distilled water, and one seed of cultivar Spillman or Chinese Spring was placed on the soil surface and covered with $10 \mathrm{~cm}^{3}$ of pasteurized Thatuna silt loam soil. Seven replicates for each isolate by cultivar treatment combination were arranged in a completely randomized experimental design (15). Cone-tainers were placed in a growth chamber with a constant temperature of $16^{\circ} \mathrm{C}(14), 80 \%$ relative humidity, and a 12-h photoperiod. Tubes were each watered with $10 \mathrm{ml}$ of distilled water as necessary. After 17 days, the experiment was terminated. Due to the large number of plants evaluated, the entire experiment was placed in the dark at $4^{\circ} \mathrm{C}$ to stop growth, and plants were randomly removed for processing over the next 5 days. Even though plants may have continued to grow, the total plant growth at such a low temperature would not be enough to cause statistical differences (32). This trial was conducted twice, and results from the two trials are hereafter referred to as trial 1 and trial 2.

Plants were washed free of soil and debris using a high-pressure stream of tap water. The number of emerged seedlings, plant height (from the soil surface to tip of the longest leaf), length of the first true leaf, and number of seminal roots were recorded. Root systems were digitally scanned using a Hewlett-Packard ScanJet 5370C scanner, and saved as TIF files. Root scans were analyzed using WinRhizo software (Regent Instruments Inc., Québec, Canada). This software calculated the total root length and number of root tips. Before analysis, scans were manually adjusted to remove shadows, overlapping root segments, and debris (22). To reduce the variability in the adjustment and analysis process, the same person was responsible for all use of the WinRhizo software in both trials.

Data analysis. Data were analyzed using SAS (Version 8.0; SAS Institute Inc., Cary, NC). Responses of each cultivar to 18 isolates of Pythium spp. were analyzed as a completely randomized design (15). Analysis of variance was conducted to test for significance of isolate and cultivar main effects, as well as to identify any significant interactions among main effects (24). The error mean square was used to test all treatment effects, which were considered fixed $(15,24)$. Least square means were obtained and compared using least significant difference (LSD) to determine significant differences between cultivars and among isolates at the $5 \%$ probability level (24). Spearman's coefficient of rank correlation (27) was used to determine the 
consistency of the ranking of isolates across trials.

\section{RESULTS}

When trials 1 and 2 were analyzed together, a significant $(P<0.05)$ isolate by trial interaction was detected for length of the first leaf, total root length, and root tip number. In addition, a significant $(P<$ 0.05 ) cultivar by isolate interaction was detected in trial 2 for total root length and root tip number. Therefore, data are presented separately for each trial and cultivar. With the exception of emergence in trial 2, isolate was a significant $(P<0.05)$ source of variation for all parameters tested, indicating that the Pythium isolates did not cause equivalent levels of damage to these cultivars. Cultivar was not a significant source of variation for any of the parameters measured in trial 1 , with the exception of length of the first leaf. In contrast, cultivar was significant for every parameter in trial 2 except for total root length, indicating that the two cultivars may differ in their response to Pythium infection.

Emergence. Only three isolates caused a significant reduction in percent emergence compared with the controls in trial 1 (Fig. 1A). Chinese Spring emerged at a rate of $57 \%$ when treated with $P$. irregulare 70007, whereas $P$. ultimum isolate 010143 and $P$. abappressorium isolate 020125 significantly reduced the emergence of Spillman to 57 and $43 \%$, respectively.

In trial 2, P. ultimum isolates 010143 and 90038 caused a $29 \%$ reduction in emergence compared with the noninoculated Chinese Spring control. P. debaryanum isolate 010114 significantly reduced the emergence of Spillman seedlings compared with the noninoculated control (Fig. 1B). No other isolate significantly reduced emergence in trial 2.

Root length. Total root length varied from 100 to $350 \mathrm{~cm}$, values similar to those obtained by Paulitz et al. (22). Total root length was reduced for both cultivars by all Pythium species tested in trial 1 compared with the control; however, variation among isolates within a species also was detected (Fig. 2A). Eight isolates caused a significant reduction in root length compared with the control for Chinese Spring in trial 1. Both isolates of $P$. ultimum and $P$. abappressorium isolate 020125 caused a significant reduction in root length compared with the noninoculated Chinese Spring control. P. ultimum isolate 90038 was the most damaging, resulting in root lengths that were $73 \%$ shorter than the noninoculated control. Fourteen isolates significantly reduced root length compared with the noninoculated Spillman control. All isolates of $P$. heterothallicum, $P$. debaryanum, Pythium sp. (aff. echinulatum), P. abappressorium, and $P$. ultimum caused a significant reduction in root length compared with the non- inoculated control for Spillman. The most severe reduction in root length for Spillman occurred with $P$. ultimum isolate 010143, resulting in root lengths that were $68 \%$ shorter compared with the noninoculated control plants.

Five isolates caused a significant reduction in total root length of Chinese Spring in trial 2, and three isolates caused a significant reduction for Spillman (Fig. 2B). $P$. heterothallicum, $P$. intermedium, $P$. rostratum, and $P$. ultimum did not reduce root length in trial 2. P. irregulare 70007 was the most damaging isolate to Chinese Spring, with a root length measuring 55\% of the noninoculated control plants. The largest reduction in root length for Spillman was caused by $P$. abappressorium isolate 020125 , which reduced root length by $35 \%$ compared with the noninoculated control.

Number of root tips. Isolates of seven of the nine Pythium species significantly reduced the number of root tips on at least one of the infected cultivars in trial $1 \mathrm{com}$ pared with the control (Fig. 3A). Isolates within these species varied in the magnitude of root tip reduction. Eight isolates significantly decreased the number of root tips on Chinese Spring compared with the noninoculated control, and seven isolates reduced the number of root tips of Spillman. Both isolates of $P$. abappressorium and $P$. ultimum caused a significant reduction in the number of root tips compared with the noninoculated control for Chinese Spring in trial 1 . No isolates of $P$. rostratum or $P$. intermedium caused a significant reduction in the number of root tips for either cultivar. The most damaging isolate, P. ultimum 90038, resulted in plants with 72 and $55 \%$ fewer root tips compared with the noninoculated controls for Chinese Spring and Spillman, respectively. $P$. debaryanum isolate 90136 also caused a large decrease in root tip number for both cultivars in trial 1 (Fig. 3A). Only two isolates (Pythium sp. [aff. echinulatum] 020151 and $P$. irregulare 70007) caused a significant reduction of root tip numbers in the second trial, and only on Chinese Spring (Fig. 3B).

Length of the first leaf. In trial 1, eight Pythium isolates within five species caused a significant reduction in the length of the first leaf, compared with the Chinese Spring and Spillman controls (Fig. 3A). P. ultimum and $P$. abappressorium caused the largest decreases in first leaf length for both cultivars. P. ultimum isolate 90038 resulted in a 59\% reduction in the length of the first leaf compared with the noninoculated Chinese Spring control, whereas $P$. abappressorium isolate 020125 caused a $43 \%$ reduction in length of the first leaf compared with the noninoculated Spillman

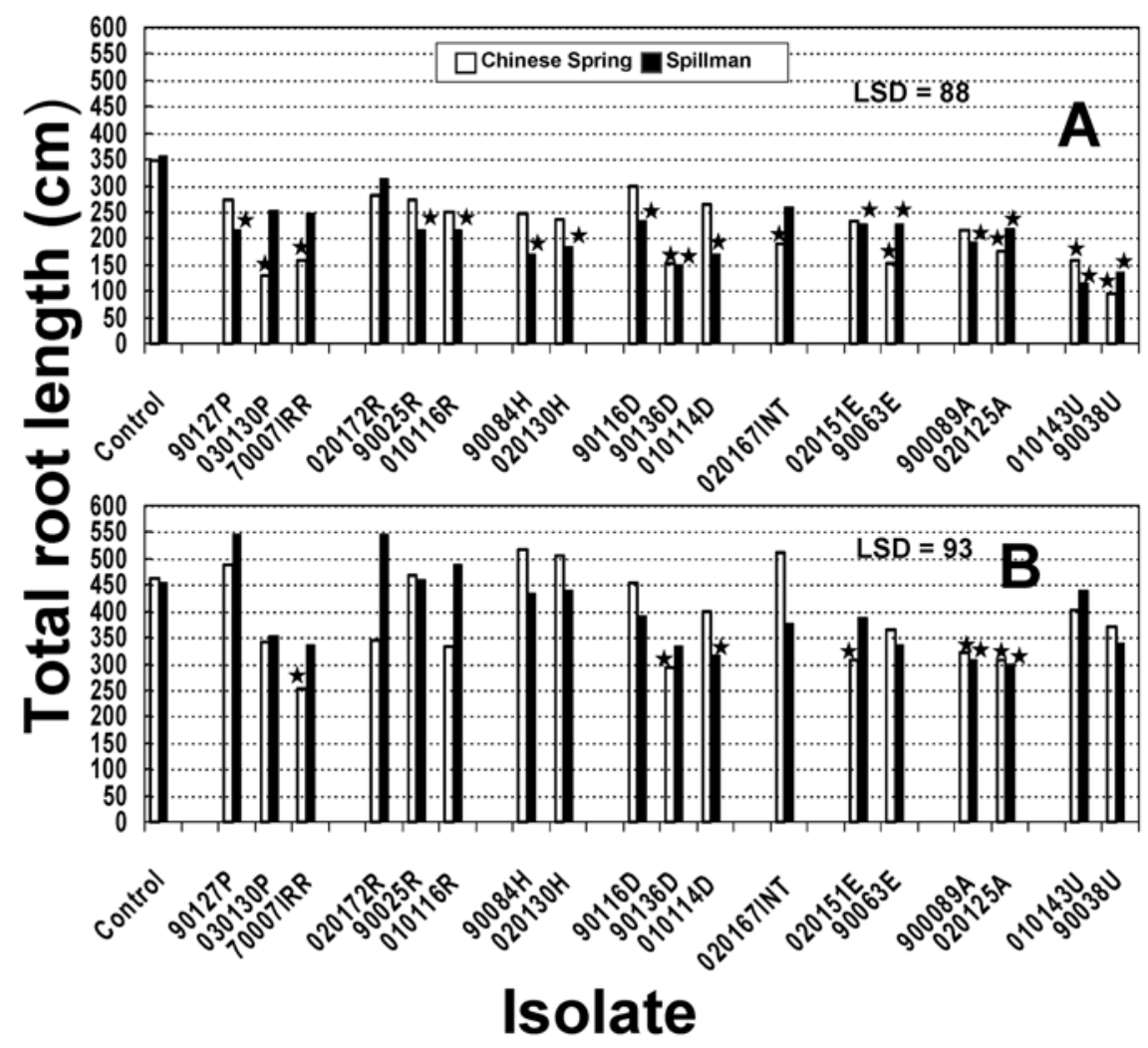

Fig. 2. Effect of isolates of Pythium on total root length of wheat cultivars Chinese Spring and Spillman $(\mathbf{A}=$ trial $1, \mathbf{B}=$ trial 2$)$. Bars with stars are significantly less than the noninoculated control treatments based on least significant difference $(P=0.05)$. LSD displayed in figure to determine significant differences among isolates was pooled across cultivars. $\mathrm{A}=P$. abappressorium, $\mathrm{D}=P$. debaryanum, $\mathrm{E}=P$. sp. $($ aff. echinulatum $), \mathrm{H}=P$. heterothallicum, $\mathrm{IRR}=P$. irregulare, $\mathrm{INT}=P$. intermedium, $\mathrm{P}=P$. paroecandrum, $\mathrm{R}=P$. rostratum, and $\mathrm{U}=P$. ultimum. 


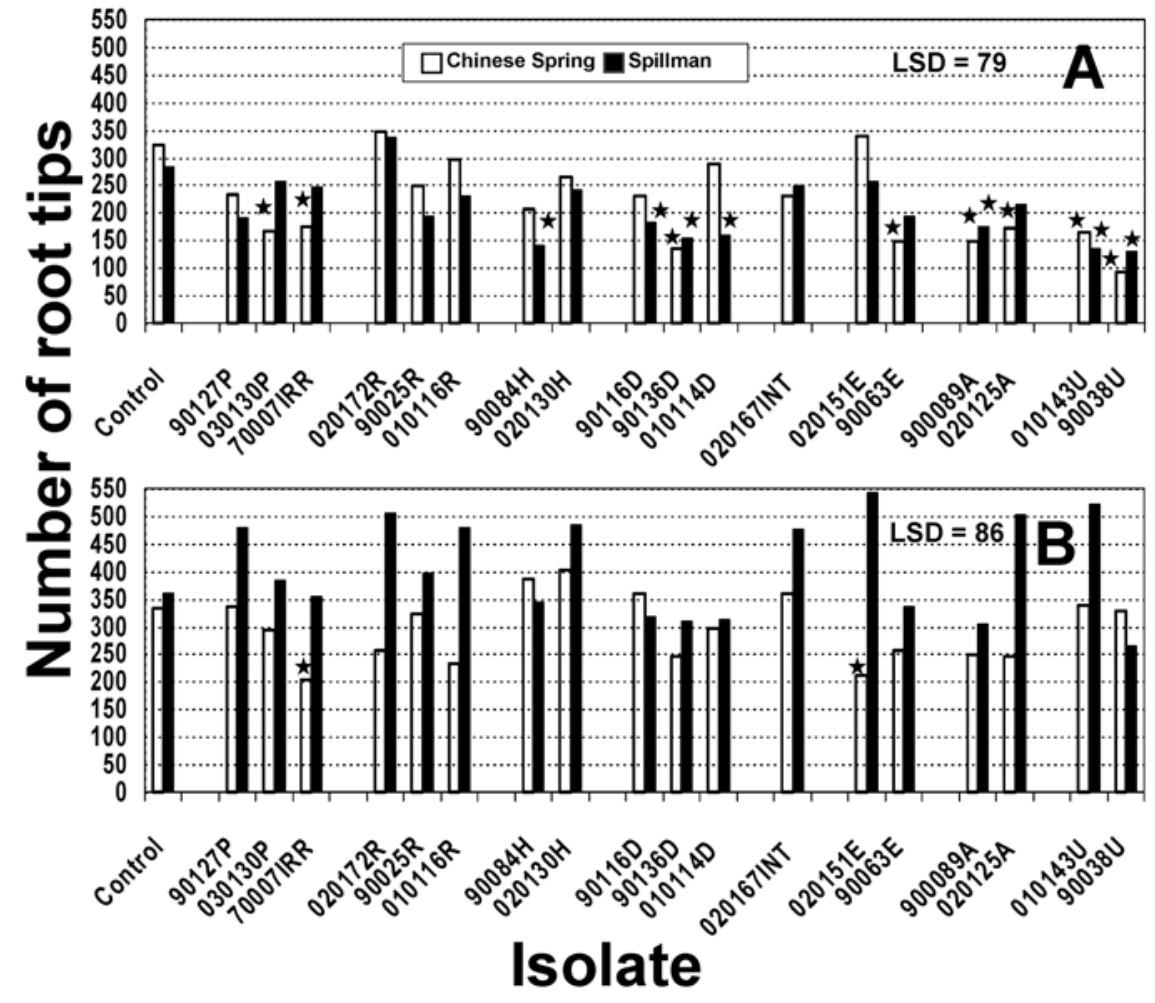

Fig. 3. Effect of isolates of Pythium on the number of root tips of wheat cultivars Chinese Spring and Spillman $(\mathbf{A}=$ trial $1, \mathbf{B}=$ trial 2). Bars with stars are significantly less than the noninoculated control treatments based on least significant difference $(P=0.05)$. LSD displayed in figure to determine significant differences among isolates was pooled across cultivars. $\mathrm{A}=P$. abappressorium, $\mathrm{D}=P$. debaryanum, $\mathrm{E}=P$. sp. (aff. echinulatum), $\mathrm{H}=P$. heterothallicum, $\mathrm{IRR}=P$. irregulare, $\mathrm{INT}=P$. intermedium, $\mathrm{P}=P$. paroecandrum, $\mathrm{R}=P$. rostratum, and $\mathrm{U}=P$. ultimum.

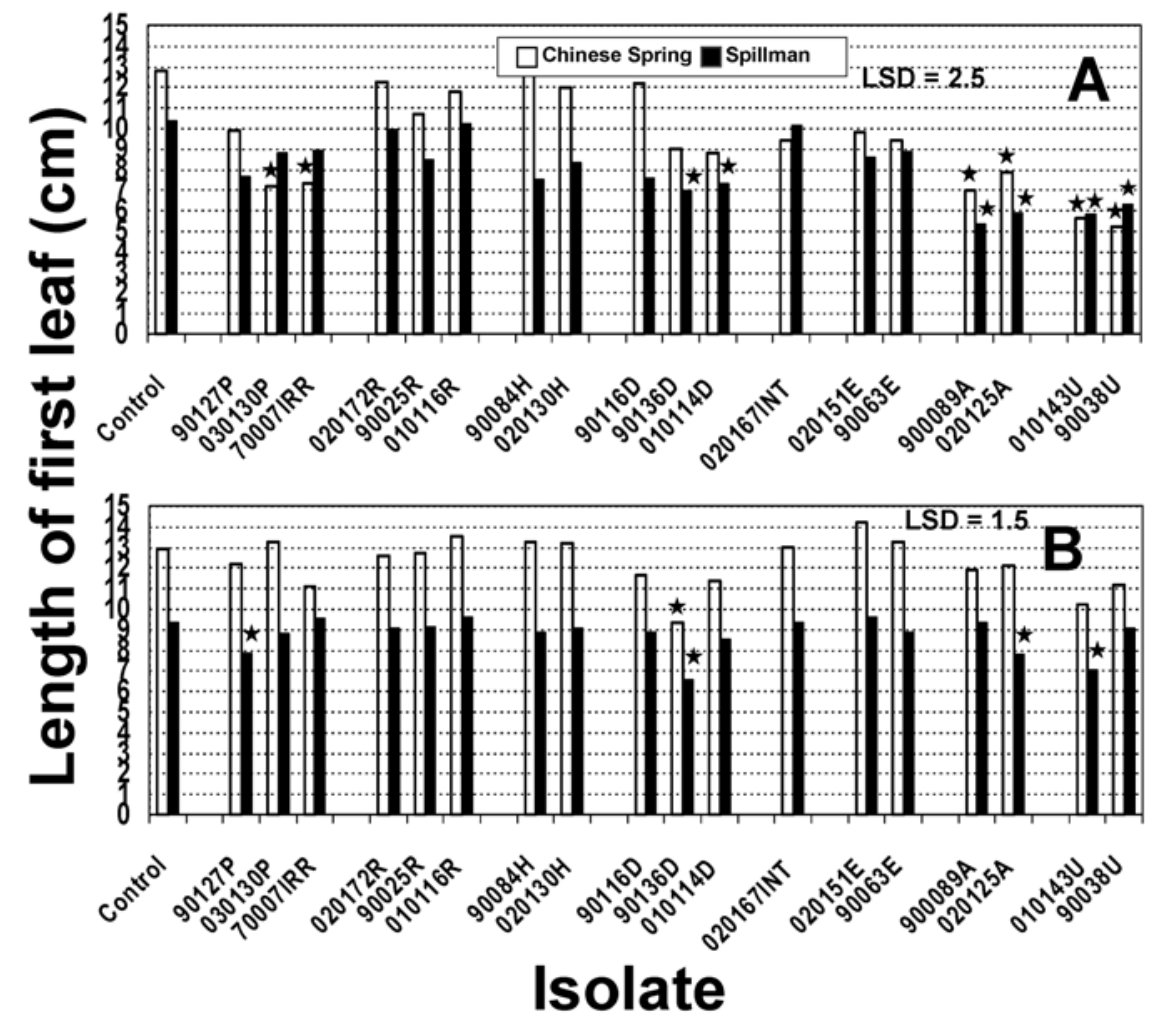

Fig. 4. Effect of isolates of Pythium on length of the first leaf of wheat cultivars Chinese Spring and Spillman $(\mathbf{A}=$ trial 1, $\mathbf{B}=$ trial 2). Bars with stars are significantly less than the noninoculated control treatments based on least significant difference $(P=0.05)$. LSD displayed in figure to determine significant differences among isolates was pooled across cultivars. $\mathrm{A}=P$. abappressorium, $\mathrm{D}=P$. debaryanum, $\mathrm{E}=P$. sp. (aff. echinulatum), $\mathrm{H}=P$. heterothallicum, $\mathrm{IRR}=P$. irregulare, $\mathrm{INT}=P$. intermedium, $\mathrm{P}=P$. paroecandrum, $\mathrm{R}=P$. rostratum, and $\mathrm{U}=P$. ultimum. control. No significant reduction in length of the first leaf was caused by any isolates of $P$. rostratum, $P$. heterothallicum, $P$. intermedium, or Pythium sp. (aff. echinulatum) in trial 1.

P. paroecandrum isolate $90127, P$. debaryanum isolate 90136, P. abappressorium isolate 020125 , and P. ultimum isolate 010143 were the only isolates that caused a significant reduction in first leaf length compared with the noninoculated Spillman control in trial 2 (Fig. 4B). P. debaryanum isolate 90136 was the most damaging to both cultivars, causing a 28 and $29 \%$ reduction in length of the first leaf compared with the noninoculated controls for Chinese Spring and Spillman, respectively.

\section{DISCUSSION}

The variables total root length, root tip number, length of the first leaf, and percent emergence were used for making virulence determinations in this study. Percent emergence, root length, and first leaf length have previously been used in virulence assays involving Pythium $(3,12,14)$, and the use of WinRhizo allowed for the determination of root tip number, which is also a good indication of Pythium infection levels $(1,7)$. Each of these variables gives a slightly different indication of how $P y$ thium affects roots.

Responses of root length indicated a variation in virulence among the Pythium species. Chamswarng and Cook (3) found $P$. ultimum to be more virulent on wheat than $P$. heterothallicum, and it was among the most virulent Pythium spp. examined. Ingram and Cook (14) demonstrated that $P$. irregulare and $P$. ultimum are more virulent on wheat than $P$. heterothallicum. Both authors used length of the longest root to assess virulence. In the current study, not all isolates within each Pythium species were equally virulent based on their effect on root length, demonstrating that isolates within a given Pythium species vary in their levels of virulence. $P$. debaryanum isolate 90136 caused a greater effect on plant variables and limited root length more than did $P$. debaryanum isolates 90116 and 010114. Furthermore, population genetics studies on $P$. ultimum detected genetic diversity within this species (10), and virulence differences would be expected given this genetic diversity.

Pythium infects root tips and root hairs $(1,7)$, and the number of root tips may be a good indicator of total Pythium infection levels. If the meristem at the root tip is killed by Pythium, no secondary branching or root tips are formed beyond that point. Levels of Pythium root infection are difficult to quantify on a visual basis due to a lack of visible symptoms (9). WinRhizo root analysis software counts the number of root tips in a scanned image and is useful when measuring the effects of disease. However, it is more difficult to obtain an accurate estimate of root tips on plants 
with large root systems due to the high frequency of root crossovers and fragments that must be removed from the files before analysis. Plants in trial 2 had larger root systems than those from trial 1 , which may account for the large number of root tips recorded for several plants in trial 2.

$P$. ultimum and $P$. debaryanum caused a reduction in first leaf length, which is an indication of embryo infection by Pythium species $(3,6,14)$. The decrease in length of the first leaf caused by P. ultimum in trial 1 is consistent with the findings of Chamswarng and Cook (3) and Ingram and Cook (14). P. abappressorium is a newly described and widely distributed species in eastern Washington State (20), which caused a reduction in the length of the first leaf in trial 1. Despite the lower overall disease in trial 2, the significant decrease in first leaf length caused by isolates of $P$. ultimum, $P$. abappressorium, $P$. debaryanum, and $P$. paroecandrum suggests that these species are the most efficient at colonizing the embryo of germinating seeds.

Only three Pythium isolates caused a significant reduction in emergence in each of the two trials. Decreased emergence, or damping-off, also is an indication that Pythium isolates have colonized the germinating embryo $(3,14)$. In practice, emergence of wheat is generally not a problem in Pythium-infested soils $(6,7)$, so it is not surprising that few differences in emergence were detected. Length of the first leaf may be a more suitable indicator of embryo infection due to the many other factors that may cause a decrease in emergence, such as seed storage conditions or undesirable environmental conditions in the field where the seed was grown. High percent emergence does not necessarily imply a lack of Pythium infection. Cook et al. (7) reported 50 to $55 \%$ of emerged wheat seedlings collected from field studies had embryos infected with Pythium.

When dealing with soilborne plant pathogens, variability between trials is inherently difficult to control. Some of the differences in the response of the two cultivars and the significant interaction between cultivars and isolates in trial 2 were most likely caused by the lower levels of inoculum potential that occurred in trial 2. Values were larger in trial 2 than in trial 1 for total root length, number of root tips, and length of the first leaf. On average, plants in trial 2 had larger root systems than plants from trial 1. Despite these differences, Spearman's coefficient of rank correlation (27) was significant $(P$ $<0.05$ ), revealing that the ranking of isolates across trials (data not shown) was consistent.

Proper determination of inoculum density is a crucial step when conducting virulence assays with Pythium. Inoculum preparation (21) and determination of spore density (2) are sensitive procedures. Inoculum density is based on a small sam- ple from the inoculum source and may be biased due to variation in spore density within that source, making it difficult to obtain equal levels of inoculum potential across trials. The inoculum in this work consisted of oospores, hyphal swellings, sporangia, and mycelium, mostly present in small colonized particles of rolled oats in the autoclaved soil. Oospores and hyphal swellings can also become dormant over time. Therefore, differences in inoculum potential may explain the differences in results between the two trials. A food base such as oatmeal or wheat chaff could be added to the soil of the experiment to increase inoculum potential. However, we chose not to do this in an effort to prevent biased results in favor of faster growing Pythium spp., which could more readily utilize the food base.

The significant cultivar effect for root tip number, first leaf length, and emergence in trial 2 may be due to genetic differences between Spillman and Chinese Spring, which were more evident in the presence of lower Pythium disease levels. Differences between Spillman and Chinese Spring also were seen when grown in the presence of $P$. ultimum and $P$. debaryanum (13). Previous research on Pythium pathogenicity involved only a single wheat cultivar $(3,14)$. Had more than one wheat cultivar been used, cultivar might have been a significant source of variation in these studies as well.

Our results indicate that variation exists among and within Pythium spp. in their level of virulence to the spring wheat cultivars Spillman and Chinese Spring. P. irregulare, $P$. debaryanum, $P$. abappressorium, and $P$. ultimum were generally more virulent than $P$. paroecandrum, $P$. rostratum, $P$. heterothallicum, $P$. intermedium, and Pythium sp. (aff. echinulatum) on the two wheat cultivars tested in this study. Paulitz and Adams (19) found P. ultimum, $P$. rostratum, $P$. heterothallicum, Pythium sp. (aff. echinulatum), P. debaryanum, and P. abappressorium to be present in 18,40 , $34,25,38$, and $50 \%$ of the sites sampled in eastern Washington, respectively. If plant breeders aim to screen wheat germ plasm for potential resistance gene donors, $P y$ thium isolate selection is an important consideration. Pythium isolates with high virulence levels would be more desirable for germ plasm evaluations. It would also be useful to screen germ plasm using $P y$ thium species that are present in the agricultural soils in which these cultivars will be grown.

Data presented here should prove useful when selecting Pythium isolates to screen wheat germ plasm to detect resistance or tolerance to Pythium root rot. $P$. rostratum, $P$. heterothallicum, and $P$. intermedium were the least virulent among species tested. In contrast, $P$. ultimum isolate 90038 and $P$. debaryanum isolate 90136 were among the most virulent isolates.
ACKNOWLEDGMENTS

We thank Kim Garland-Campbell, USDA-ARS, Pullman, WA, for her assistance with experimental design and statistical analyses, and R. James Cook, Dept. of Crop and Soil Sciences and Department of Plant Pathology, Washington State University, for his technical advice on Pythium pathology. Funding for this project was provided by the O.A. Vogel Fund (project no. 8334) and the College of Agriculture and Home Economics at Washington State University.

\section{LITERATURE CITED}

1. Bruehl, G. W. 1953. Pythium root rot of barley and wheat. U.S. Dep. Agric. Tech. Bull. 084.

2. Chamswarng, C. 1984. Etiology and epidemiology of Pythium root rot of wheat. Ph.D. diss. Washington State University, Pullman.

3. Chamswarng, C., and Cook, R. J. 1985. Identification and comparative pathogenicity of $P y$ thium species from wheat roots and wheatfield soils in the Pacific Northwest. Phytopathology 75:821-827.

4. Cook, R. J. 1992. Wheat root health management and environmental concern. Can. J. Plant Pathol. 14:76-85.

5. Cook, R. J., Chamswarng, C., and Tang, W.-H. 1990. Influence of wheat chaff and tillage on Pythium populations in soil and Pythium damage to wheat. Soil Biol. Biochem. 22:939-947.

6. Cook, R. J., and Haglund, W. A. 1991. Wheat yield depression associated with conservation tillage caused by root pathogens in the soil not phytotoxins from the straw. Soil Biol. Biochem. 23:1125-1132.

7. Cook, R. J., Sitton, J. W., and Haglund, W. A. 1987. Influence of soil treatments on growth and yield of wheat and implications for control of Pythium root rot. Phytopathology 77:11921198.

8. Cook, R. J., Sitton, J. W., and Waldher, J. T. 1980. Evidence for Pythium as a pathogen of direct-drilled wheat in the Pacific Northwest. Plant Dis. 64:102-103.

9. Cook, R. J., and Veseth, R. J. 1991. Wheat Health Management. American Phytopathological Society, St. Paul, MN.

10. Francis, D. M., Chelen, M. F., and St. Clair, D. A. 1994. Genetic variation in homothallic and hyphal swelling isolates of Pythium ultimum var. ultimum and Pythium ultimum var. sporangiferum. Mol. Plant-Microb. Interact. 7:766-775.

11. Fukui, R., Campbell, G. S., and Cook, R. J. 1994. Factors influencing the incidence of embryo infection by Pythium spp. during germination of wheat seeds in soils. Phytopathology 84:695-702.

12. Hering, T. F., Cook, R. J., and Tang, W.-h 1987. Infection of wheat embryos by Pythium species during seed germination and the influence of seed age and soil matric potential. Phytopathology 77:1104-1108.

13. Higginbotham, R. W., Paulitz, T. C., Campbell, K. G., and Kidwell, K. K. 2004. Evaluation of adapted wheat cultivars for tolerance to $\mathrm{Py}$ thium root rot. Plant Dis. 88:1027-1032.

14. Ingram, D. M., and Cook, R. J. 1990. Pathogenicity of four Pythium species to wheat, barley, peas and lentils. Plant Pathol. 39:110-117.

15. Kuehl, R. O. 2000. Design of Experiments: Statistical Principles of Research Design and Analysis. 2nd ed. Duxbury Press, Pacific Grove, CA

16. Middleton, J. T. 1943. The taxonomy, host range, and geographic distribution of the genus Pythium. Mem. Torrey Bot. Club 20:1-171.

17. Mircetich, S. M., and Kraft, J. M. 1973. Efficiency of various selective media in determining Pythium populations in soil. Mycopathol. Mycol. Appl. 50:151-161.

18. Pannkuk, C. D., Papendick, R. I., and Saxton, K. E. 1997. Fallow management effects on soil water storage and wheat yields in the Pacific 
Northwest. Agron. J. 89:386-391.

19. Paulitz, T. C., and Adams, K. 2003. Composition and distribution of Pythium communities in wheat fields in eastern Washington State. Phytopathology 93:867-873.

20. Paulitz, T. C., Adams, K., and Mazzola, M. 2003. Pythium abappressorium - A new species from eastern Washington. Mycologia 95:80-86.

21. Paulitz, T. C., and Baker, R. 1987. Biological control of Pythium damping-off of cucumbers with Pythium nunn: Influence of soil environment and organic amendments. Phytopathology 77:341-346.

22. Paulitz, T. C., Smith, J. D., and Kidwell, K. K. 2003. Virulence of Rhizoctonia oryzae on wheat and barley cultivars from the Pacific Northwest. Plant Dis. 87:51-55.

23. Smith, J. D., Kidwell, K. K., Evans, M. A., Cook, R. J., and Smiley, R. W. 2003. Evalua- tion of spring cereal grains and wild Triticum germplasm for resistance to Rhizoctonia solani AG-8. Crop Sci. 43:701-709.

24. Snedecor, G. W., and Cochran, W. G. 1967. Statistical Methods. 6th ed. Iowa State University, Ames.

25. Sprague, R. 1944. Root rots of cereals and grasses in North Dakota. N. Dak. Agric. Exp. Stn. Bull.

26. Sprague, R. 1946. Root rots and leaf spots of grains and grasses in the northern Great Plains and western states. Plant Dis. Rep., Suppl. 163:101-268.

27. Steele, R. G. D., and Torrie, J. H. 1997. Principles and Procedures of Statistics: A Biometrical Approach, 3rd ed. McGraw-Hill, New York.

28. U.S. Dep. Agric., Nat. Agric. Stat. Serv. 2000. 2000 Washington Agricultural Statistics. Published online.
29. Vanterpool, T. C. 1938. Some species of $P y$ thium parasitic on wheat in Canada and England. Ann. Appl. Biol. 25:528-543.

30. Vanterpool, T. C., and Truscott, J. H. L. 1932 Studies on browning root rot of cereals II Some parasitic species of Pythium and their relation to the disease. Can. J. Res., Sect. C 6:68-93.

31. Veseth, R., and Wysocki, D. 1990. Pacific Northwest Conservation Handbook. Washington State Univ. Coop. Ext. Publ. MISC0136.

32. Vincent, C. D., and Gregory, P. J. 1989. Effects of temperature on the development and growth of winter wheat roots I. Controlled glasshouse studies of temperature, nitrogen and irradiance. Plant Soil 119:87-97.

33. Weller, D. M., and Cook, R. J. 1986. Increased growth of wheat by seed treatments with fluorescent pseudomonads, and implications of $P y$ thium control. Can. J. Plant Pathol. 8:328-334. 